Título artículo / Títol article:

Equipment investment, output and productivity in China

Autores / Autors

María Jesús Herrerías Talamanes, Vicente Orts Ríos

Revista:

Empirical Economics

Versión / Versió:

Preprint

Cita bibliográfica / Cita bibliogràfica (ISO 690):

HERRERÍAS TALAMANTES, María Jesús; ORTS RÍOS, Vicente. Equipment investment, output and productivity in China. Empirical Economics, 2012 , vol. 42, no 1 .

url Repositori UJI:

http://hdl.handle.net/10234/63257 


\title{
Equipment Investment, Output and Productivity in China'
}

\author{
M.J. Herrerias ${ }^{\dagger}$ and Vicente Orts \\ †Department of Economics, Universitat Jaume I \\ $\ddagger$ Department of Economics and Institute of International Economics, Universitat Jaume I
}

\begin{abstract}
At the beginning of the nineties J. Bradford De Long and Lawrence H. Summers highlighted in a series of influential papers that there were good reasons and quantitative evidence to support the point of view that machinery and equipment investment might be strongly associated with economic growth. China and its enormous investment effort over recent decades constitutes an interesting case study with which to analyse the role played by equipment investment in its recent economic performance and its interaction with other sources of growth, i.e. openness, R\&D, human capital, and infrastructures. Our results provide evidence that equipment investment and exports are one of the most important determinants of both labour productivity and output in the long run even after controlling for other sources of growth in China. Furthermore, when human capital and infrastructures are included, we found that they have a positive effect on economic activity in the long run.
\end{abstract}

Key words: Growth, Equipment Investment, Infrastructure, Exports, Human Capital

J.E.L. Classification: F43, O40, O47, 053

${ }^{1}$ Corresponding author: Department of Economics, Universitat Jaume I, Avda. Sos Baynat s/n, 12071 Castellón (Spain). Tel.: +34 9647286 15; fax: +34 9647285 91. Email orts@eco.uji.es and herreria@eco.uji.es 


\section{Introduction}

At the beginning of the nineties J. Bradford De Long and Lawrence H. Summers highlighted in a series of influential papers that there were good reasons and quantitative evidence to support the point of view that machinery and equipment investment might be strongly associated with economic growth. Specifically, they found that "those countries with high equipment investment grew extremely rapidly, even after controlling for a number of other factors". ${ }^{2}$ They identified at least three arguments that support their view. Firstly, historical accounts of economic growth invariably assign a central role to mechanization. Secondly, discussions of economic growth in development economies and the new growth theory traditions underline external economies as an important cause of growth. In addition, given that the equipment sector is one of the most intensive in research and development, it is reasonable to believe that it could be a source of external economies. Thirdly, countries that pursue a government-led "developmental state" approach to development seem to have higher equipment investment rates, lower equipment prices, and enjoy faster economic growth. ${ }^{3}$

From our point of view, the rapid growth in China and its enormous investment effort over recent decades constitutes an interesting case study in which to analyse the role of equipment investment and its interaction with other sources of growth in the recent economic performance of the country over the period 1964-2004. ${ }^{4}$ In the case of the Chinese economy, investment was a key factor in stimulating economic growth during the pre-reform period (before 1978). After the economy was opened up to the international market, however, nobody questions the fact that exports have become one of the main determinants in the process of growth, and the extensive export promotion leads to an export-led growth effect. Nonetheless, there are reasons to believe that during the post-reform period investment (and especially equipment investment) has also played a significant role in economic growth in China. ${ }^{5}$ This belief is based on the change in the composition of investment that took place before the end of the seventies, with a significant contribution being made by equipment as opposed to other components of capital accumulation such as infrastructures. This could be seen quite clearly in the massive investment infrastructure projects that were implemented during the pre-reform period, and grew more modestly later on. In

\footnotetext{
${ }^{2}$ De Long and Summers, (1992, p.158)

${ }^{3}$ De Long and Summers, (1991, pp.447-448)

${ }^{4}$ This period was selected with the aim of avoiding the turbulent period during the Great Leap Forward (1958-1961) and its consequences on the economy.
} 
addition, the components of equipment investment were diversified, because the pre-reform period was characterized by the acquisition of complete plants in order to increase the productivity capacity, whereas since the end of the seventies the focus was on renewal and updating of existing obsolete production facilities, so as to improve efficiency and productivity.

In addition to these arguments, and from a theoretical point of view, the recent literature on endogenous growth (and more especially the Schumpeterian version of the endogenous growth theory) provides formal support for the existence of a long-term relationship between investment and growth in which the causation runs from investment to output and productivity. In this sense, capital accumulation could be a source of long-run economic growth if embodied technological progress exists and if supply factors predominate among the determinants of capital accumulation (Madsen, 2002). Thus, capital accumulation and knowledge can determine the level of output in the long run, both factors being complementary processes that play a significant role in economic growth (Howitt and Aghion, 1998, p. 112).

The contribution of this paper to the literature is threefold. First, we provide evidence of the role played by equipment investment as a determinant of output and labour productivity in China for the period 1964-2004. To the best of our knowledge no evidence of the effect of equipment investment on labour productivity and output in China has been published to date. Thus, unlike other studies, such as Chow $(1993,2008)$ and Chow and Li (2002), we break the accumulation of physical capital down into equipment investment and infrastructures. Second, we assess its robustness by allowing for other relevant sources of economic growth, like openness, R\&D expenditure, and human capital among others. If these factors are relevant determinants of output and productivity and are simultaneously sources of potential interactions with each other, only a unified framework and a joint estimation procedure can allow their influence on output and productivity to be estimated properly, while also avoiding the bias in our results due the endogeneity of different variables. This is why, empirically, we employed the cointegrated VAR model proposed by Johansen (1988 and 1995) and Johansen and Juselius (1990 and 1994), while allowing for the existence of multiple long-run relationships. Lastly, in contrast to the works that employ growth accounting methods like Borenzstein and Ostry (1996), Hu and Khan (1997), Ezaki and Sun (1999), Young (2003) or Wang and Yao (2003), among others, we establish causality relations among the potential determinants of growth and output and productivity in both

\footnotetext{
${ }^{5}$ See, for example, Chow (1993).
} 
the short and the long run.

The rest of the paper is set out as follows. Section 2 contains a review of the literature on the relationship between equipment investment and its related variables and economic growth. Section 3 contains a description of the variables considered and the methodology used. Section 4 shows the empirical results. Finally, section 5 includes the conclusions that were drawn.

\section{Literature Review}

In Solow-type economic growth models, the long-run growth of productivity is given by the exogenous growth rate of technological progress. In this setting neither capital accumulation nor government policies can have any effect on the long-run growth rate. However, the new growth theory grants technological change a greater role in the growth process. In these models, innovation activities enhance output and labour productivity in the long run by increasing the qualities and productivity of different factors in the production process and stimulating capital investment. ${ }^{6}$ In particular, the "AK" models and the Schumpeterian version of endogenous growth theory, developed by Aghion and Howitt (1992), emphasized the strong association between capital accumulation and long-run economic growth. In both approaches capital accumulation, that is investment, is the most important factor that causes economic growth, but only the latter highlights the importance of embodied technological progress, thus establishing a complementary point of view with the Solow model. ${ }^{7}$ Furthermore, investment and innovation activities maintain a close relationship given that "technological innovations are typically embodied in a durable good, either physical or human capital" (Aghion and Howitt, 1999, p.93). Nevertheless, there are good reasons to believe that, among the components of capital accumulation, machinery and equipment investment are the best candidates to incorporate technological progress. As De Long and Summers (1991 and 1992) pointed out, those countries with higher equipment investment rates tend to grow faster. According to those authors, these findings are likely to be related to the fact that the equipment investment sector is intensive in $R \& D$ expenditure, and also to a research sector that is highly "capital-using" and where external economies could exist. They emphasize the empirical relevance and the interdependence of these factors, capital accumulation and technological progress, which influence the dynamics of output and labour productivity stressed in

\footnotetext{
${ }^{6}$ Romer (1986) argued that it is the new investment that stimulates productivity instead of the capital stock.
} 
the Schumpeterian growth model. Capital accumulation requires new, advanced technology embodied in new investments, given the diminished returns on capital, and at the same time new technologies need investments so that they can be implemented in the production process, which favours the accumulation of capital and boosts economic development.

However, it is difficult to believe that until now the Chinese economy has had a comparative advantage in the production of R\&D intensive equipment investment. Instead, the Chinese economy, as is probably the case in other developing countries, has made use of imported capital goods from advanced economies with R\&D intensive equipment sectors. Access to cheaper capital goods from more developed countries has two complementary effects. First, it allows developing countries to accumulate more capital, and to do so more efficiently and, second, imported capital goods become a source of positive spillovers for recipient economies. Related with this latter effect, the existence of domestic innovation activities becomes very important. Domestic innovation activities facilitate a more efficient use of imported capital goods and the spread of embodied technological progress to the rest of the economy, thereby encouraging further capital accumulation and domestic imitation and innovation (Lee, 1995; Eaton and Kortum, 2001; Boileau, 2002; Caselli and Wilson, 2004).

The empirical relationship between equipment investment and economic growth has been widely studied with mixed results. Auerbach et al. (1994), for example, argued that the De Long and Summers' results (1992) exaggerate the social returns on equipment investment. Using De Long and Summers' data set they found that if Botswana was removed from the sample, the effect of equipment investment on economic growth was consistent with the predictions of the traditional models of economic growth. Additionally, Blomström et al. (1996) address the issue of the directions of influence between equipment investment and growth, and they find no evidence that equipment investment causes growth, but instead that growth over a period is more closely related to subsequent capital formation than the opposite way round. In contrast to these authors, Temple (1998) reinvestigates these contradictions using a framework that is an improved version of the work of De Long and Summers. The results of that study show that for developing countries, as argued by De Long and Summers, equipment investment is especially important and that a simple Solow model does not seem adequate for describing growth in these countries. Additionally,

7 According to these authors, "Neoclassical Theory can be seen as a special case of modern endogenous growth theory, the special case in which the marginal productivity of efforts to innovate has fallen to zero", Aghion and Howitt (2007, p.80). 
Dellas and Koubi (2001) argued that De Long and Summers had missed the social capabilities that are crucial for poor countries to benefit through industrialization. These authors, like Temple and Voth (1998), found that industrial employment is more decisive than equipment investment in the process of development in low-moderate income countries. From another point of view, Griliches and Jogerson (1966), Hulten (1992) and Greenwood et al. (1997) found evidence that embodied technological change positively affects long-run productivity. Conversely, Berglas (1965) found no evidence of embodied technological progress and supported the Solow-type model. Finally, although to our knowledge there is no evidence of a relation between equipment investment and economic growth for China, most studies have found that capital accumulation is one of the main determinants of its long-run growth (Chow, 1993; Yusuf, 1994; Yu, 1998; Kwan et al., 1999; Herrerias and Orts, 2009 and 2010). Unlike these works, we consider equipment investment together with other factors of growth, such as openness, R\&D activities, human capital, and infrastructures in a joint model so as to establish casual relationships that make it possible to establish multiple cointegrating relations and to differentiate between short- and long-run effects, which is one of the goals of this paper.

The introduction of these additional variables seeks to fulfil several objectives. On the one hand, the aim is to check the robustness of equipment investment as a determinant of Chinese growth, while preventing bias from occurring in our estimates due to the omission of relevant variables in the specification of the empirical model. On the other hand, and taking into account the potential interactions with each other, they are introduced in order to examine their direct influence on labour productivity and output.

The economic development and growth literature provides a number of reasons to support the positive effects of openness to trade on output and productivity. Furthermore, in the case of China, openness, and especially the expansion of exports, has been considered as one of the main determinants of its more recent economic performance. Among the channels identified in the literature as potential generators of these positive effects, the most immediate is the self-selection of the firms associated with openness. If only the most productive firms can survive and participate in the trade activity due to the existence of sunk costs associated with entry into foreign markets, the least productive firms will be forced to leave and the reallocation of market shares towards the more productive firms will give rise to an increase in aggregate productivity and 
output (Melitz, 2003) ${ }^{8}$ In addition, access to foreign markets positively affects productivity in the presence of economies of scale (Helpman and Krugman, 1985). However, the literature on openness to trade and growth emphasizes knowledge spillovers as well as the ability to imitate foreign competitors' products as the main mechanisms that could speed up growth (Grossman and Helpman, 1991; Rivera-Batiz and Romer, 1991). Increased competitive pressure and interaction with firms from other countries stimulate learning-by-doing processes and favour the adoption of more efficient management and organizational styles by firms, as well as improved production techniques, which in turn increases labour training and investment in R\&D (Young, 1991; Chuang, 1998; Clerides et al., 1998). Furthermore, experience in exporting seems to be significant in determining the export mix, which suggests that there may be a trade-induced component of learning-by-doing in foreign trade specialization (An and Iyigun, 2004). All these factors enhance the productivity and output of exporting firms, which can in turn generate positive externalities in the rest of the economy (Feder, 1983; Clerides et al., 1998). Finally, exporting activity allows foreign exchange constraints to be relaxed, thus permitting increased imports of capital and intermediate goods (Esfahani, 1991; Riezman et al., 1996). Despite these arguments, there are authors who are a little sceptical about the positive effects of openness to trade on economic growth (Rodrik, 1999; Rodriguez and Rodrik, 2001). ${ }^{9}$

Human capital is also a recurring factor in the literature that is considered to promote long-run growth (Uzawa, 1965; Lucas, 1988; Romer, 1990; Young, 1991; Caballé and Santos, 1993; Howitt and Aghion, 1998; Barro, 2001). Among the different mechanisms through which human capital could enhance productivity and output, one of the most immediate is that labour productivity may rise in response to an increase in the level of skilled workers. Workers with a better education and more qualifications are expected to contribute to increase the firm's productivity. Moreover, the knowledge acquired by qualified workers, that is to say human capital, could also generate innovations or improve the ability of an economy to absorb, adapt or imitate new technologies that also have a positive effect on output and productivity, thereby reducing the technological gap from advanced countries (Benhabib and Spiegel, 1994; Nelson and Phelps, 1996, Borenztein et al., 1998; Temple and Voth, 1998; Hendricks, 2000). Thus, innovations are not confined to R\&D expenditure, but are also related to human capital. Workers' skills could increase the productivity

\footnotetext{
${ }^{8}$ This aspect was studied empirically by Bernard and Jensen (1999) for the USA and empirical evidence was later collected for different countries (Clerides et al., 1998; Aw et al., 2000).
} 
of physical capital, especially for machinery and equipment, by improving the learning-by-doing mechanism (since R\&D activities and human capital are both relevant factors) and thus raising efficiency and productivity. Lastly, there are additional education externalities that could affect long-run growth. For example, skilled workers can show their knowledge to unskilled workers and thereby improve their productivity or there may be external social impacts, given that workers with a better education are associated with a better environment, greater social cohesion, community participation, and so forth (Sianesi and Reenen, 2003).

Last but not least, since the seminal papers by Aschauer (1988, 1989), infrastructure has been considered a factor to boost long-run growth through the positive externalities that it generates in an economy. Productive infrastructure can expand the productive capacity of an area by increasing resources and by enhancing the productivity of existing resources (Munnel, 1992). Moreover, infrastructure can stimulate other forms of investment, which is favoured by the decrease in the cost of intermediate inputs and provides highly valuable services that firms employ in their production processes. Hence, it allows firms to increase their ability to engage in new productive activities (Munnel, 1992; Fernald, 1999; Röller and Waverman, 2001; Hulten et al., 2006). However, in the case of infrastructures the most relevant question is probably how productively the economy uses these infrastructures, rather than the direct effect they have on output and labour productivity. Empirically, the direction of the causality and the positive, negative or negligible effect of infrastructures on economic growth seem to be mixed. In his pioneering study, Aschauer (1989) found that infrastructure did account for labour productivity in the USA, where the direction of the causality runs from infrastructure to productivity. Similar results were found by Munnell (1990a and 1990b), Eisner (1991), Canning et al. (1994), Easterly and Rebelo (1993) and Flores de Frutos and Pereira (1993), to cite just a few. In contrast, in a study of 43 developing countries, Deverajan et al. (1996) found that transport and communication expenditures have a negative correlation with per-capita GDP growth. Similar results were found by Holtz-Eakin (1994) and Garcia-Mila et al. (1996) with different specifications.

The evidence on the relation between these additional factors and economic growth in China is unequal. Wang and Yao (2003) and Heckman (2005), for example, found that human capital has contributed positively to economic growth in China. ${ }^{10}$ Additionally, a lot of empirical work has

${ }^{9}$ There is immense body of empirical literature on the relationship between trade and economic growth, with mixed results. Recent surveys can be found in Baldwin (2003) and Lopez (2005).

${ }^{10}$ See also Lai et al. (2006), Liu (2007). 
been carried out that highlights the fact that trade, especially exports, has played a relevant role in the Chinese development. ${ }^{11}$ In many cases the causality found between exports and output or labour productivity is bidirectional. Nonetheless, Hsiao and Hsiao (2006) found that exports do not cause output. Lastly, evidence of the relationship between infrastructure and economic growth in China has been studied mainly at a regional level. On the one hand, Démurger (2001) found that transport facilities are a key differentiating factor in explaining the growth gap, and points to the role of telecommunications in reducing the burden of isolation. On the other hand, Fan and Zhang (2004) found that rural infrastructure and education play a more important role in explaining the difference in rural non-farm productivity than agricultural productivity.

In all cases, the empirical work in this field has been subject to debate over the endogeneity of different variables ${ }^{12}$ as well as over the direction of the causality running among the different factors mentioned and economic performance. For example, Bils and Klenow (2000) found reverse causality between growth and human capital, Helpman (1988) found empirical evidence that countries with higher incomes engage in more trade, and in Tatom (1993) we can find that the causation may run more from output to infrastructure capital. Thus, from an empirical point of view, and even though the issue of whether the role played by the different potential determinants of output and labour productivity and the direction of the causality between them have been extensively analysed, the results still seem to be far from conclusive. This paper attempts to clarify the nature of these economic relations in the case of the Chinese economy.

\section{Data and Methodology}

In our empirical analysis the effective sample covers annual data from the Chinese economy from 1964 to 2004. Our data set consists of GDP $(g d p)$ or labour productivity ${ }^{13}$ - output per worker - (prod), together with net equipment investment (equip), R\&D expenditure ${ }^{14}(r d)$, exportto-GDP ratio - exports in FOB terms - $(x / g d p)$, the real exchange rate $(r e r),{ }^{15}$ the investment in human capital $(h c)$ and two measures of infrastructures (rail and high); all the variables are in real

\footnotetext{
${ }^{11}$ Shan and Sun (1998) provide a comprehensive survey of the empirical evidence on export-led growth in China.

${ }^{12}$ This aspect has been especially relevant in the empirical literature on trade and growth. See, for example, Frankel and Romer (1999).

${ }^{13}$ In this paper, labour productivity and human capital were corrected by applying the methodology suggested by Nielsen (2004).

${ }^{14}$ We took total expenditure on scientific research from the NBS as a proxy variable of R\&D expenditure.

${ }^{15}$ The real exchange rate was calculated using the nominal exchange rate between the Chinese currency and the US \$ (Renminbi/\$) and the respective consumer price indices (CPIs).
} 
terms ${ }^{16}$ and are expressed in natural logarithms (except the ratio of exports to GDP and the investment of human capital). Our basic data source was the National Bureau of Statistics of China (NBS), except for equipment investment and human capital. The equipment investment variable was taken from Holz (2006), who attempted to obtain this measure based on the data concerning investment in fixed assets from the NBS. ${ }^{17}$ In addition, we took human capital, $(h c)$ - per capita years of schooling - from Wang and Yao (2003) and we extended this data to 2004 by making a small variation in the construction of the variable. ${ }^{18}$ Lastly, we employed four measures or indicators of infrastructures. On the one hand, we introduced two single measures of the length of railways and highways in operation (in $\mathrm{km}$ ) and, on the other hand, we considered the number of passenger-km of railways (100 million people passenger-km) and the number of passenger-km of highways (100 million people passenger-km) - rail and high - respectively. Thus, we considered not only infrastructure investment but also the demand for infrastructures.

In many countries, problems exist regarding the quality of statistics, and China is no exception. In the pre-reform period the statistics were based on the Material Product System and followed the material production approach. After the reforms, however, the National Bureau of Statistics (NBS) began to implement its statistics according to the System of National Accounts, a similar system to that used by developed countries. The NBS has made incessant efforts to improve the quality of China's statistics through continuous reviews over the whole period and this was more especially so in the last review, which took place in 2004 and is the compilation that has been used in this paper. ${ }^{19}$

In addition, there is a debate concerning the analyses that include joint data from the prereform and post-reform periods in the Chinese economy. In fact, the change from a planned economy to a market economy was not as drastic as some critics argue in the literature. This is due to one particular characteristic of these economic transformations, which is that they were implemented gradually (Perkins, 1994). In this sense, there is empirical evidence that makes joint use of official time series for both periods in China. For example, Chow (2004) and Holz (2005)

\footnotetext{
${ }^{16}$ We have deflated R\&D expenditure with the GDP deflator.

17 See Holz (2006) for further details on the construction of this variable, depreciation and deflators.

18 The data of human capital from Wang and Yao (2003) cover the period 1952-1999; we have extended their data by calculating a percentage of success for each level of education in order to obtain the number of graduates for the years between 2000 and 2004. Data were taken from the NBS, which cover the extended period from 1952-2004.

${ }^{19}$ For further discussion supporting the quality of Chinese statistics, see Bai et al. (2006) and Chow (2006).
} 
argue that even though the data present some problems, inaccuracies may be tolerated in the levels of the variables for the purpose of studying the long-term trend. ${ }^{20}$

Nevertheless, although Chinese National Accounts started in 1952, we moved the beginning of the effective sample to 1964 . This change was due to the difficulty involved in performing a sufficiently homogenous treatment over such a turbulent period as the one between 1958 and 1962, with the Great Leap Forward and the consequent economic collapse that produced abnormally low values of macroeconomic aggregates for the period 1961-1963. ${ }^{21}$ However, it is well known that the period under study is not free of shocks, and this led us to use different level-shift dummies and unrestricted permanent dummies in the empirical analysis to guarantee a reasonable stability of the parameters estimated in the concentrated version of the model. ${ }^{22}$

As a statistical framework for analysis, and given the potential interdependence and endogeneity of the variables considered, we used the cointegrated VAR model proposed by Johansen (1988 and 1995) and Johansen and Juselius (1990 and 1994) as the most suitable methodology for the description of our macroeconomic time series data. One of the advantages of this methodology is the possibility of combining long-run and short-run information in the data by exploiting the cointegration property (Juselius, 2007). Thus, we can find long-run economic relationships and their dynamics among the variables considered to test some predictions of economic theory. Furthermore, researchers do not impose any restrictions prior to starting the analysis with regard to the exogeneity or endogeneity of the variables we considered. Thus, given the complex relationship that exists from an economic point of view, we allow the data to reveal the nature of the variables and interactions among them.

More specifically, we start out with an unrestricted VAR model, with a restricted linear trend in the cointegration space:

\footnotetext{
${ }^{20}$ Additionally, it is possible to find other works using pre- and post-reform data and cointegration techniques. See Chow (1987), Li (2000), Yao (2000), or Phylaktis and Girardin (2005), among others.

${ }^{21}$ See Chow (1993).

${ }^{22}$ During the analyzed period the Chinese economy underwent major structural changes that must be taken into account. Among them, only to cite the most relevant, in this period occurs the Cultural Revolution (1966-1976), the openness and market-oriented reforms, which began in 1978 but was accentuated in the mid-eighties, or the events that took place in Tiananmen Square in 1989.
} 


$$
\begin{aligned}
\Delta X_{t}=\alpha \beta^{\prime} & \left.\begin{array}{l}
X \\
t \\
D_{s}
\end{array}\right)_{t-1} \\
\varepsilon_{t} \sim \operatorname{NIID}(0, \Omega) \quad & +\sum_{i=1}^{k-1} \Gamma_{i} \Delta X_{t-i}+\sum_{i=0}^{k-1} \theta_{i} \Delta D_{s t-i}+\varphi D_{t}+\mu+\varepsilon_{t}
\end{aligned}
$$

where $X_{t}$ is the vector of potentially endogenous variables in the different models that we will go on to specify; $\alpha$ and $\beta$ ' are matrices of dimension $p \times r ; \alpha$ denotes the direction and speed of adjustment towards equilibrium and $\beta$ ' is the matrix of the cointegrated vectors. $D_{s t}$ is the restricted matrix of the level-shift dummies, $\left(\Gamma_{i}, \theta_{i}, \varphi\right)$ are the coefficients of the unrestricted matrix in the short run and dummies, respectively, and $\mu$ is a vector of unrestricted constants. ${ }^{23}$ Finally, we assumed that the error term, $\varepsilon_{t}$, is an i.i.d. Gaussian sequence $N(0, \Omega)$ and the initial values, $\mathrm{X}$. ${ }_{\mathrm{k}+1}, \ldots \mathrm{X}_{0}$, are fixed.

Given that the analysis of a system containing a large number of potentially endogenous variables is econometrically very demanding, a specific-to-general approach to the choice of variables was adopted, as in Juselius and MacDonald (2000 and 2004). Initially, we started the analysis with a five-dimensional system that alternatively included the GDP or labour productivity, together with net equipment investment, R\&D expenditure, export-to-GDP ratio, and the real exchange rate (the base model). Then we extended it by including human capital and infrastructures.

The stationary property of our variables was explored with two traditional unit root tests (the Augmented Dickey Fuller and Phillips-Perron tests), as can be seen in the Appendix (Table A1). We concluded that the best characterization of our stochastic process is to accept that all variables are integrated of order one on levels.

Finally, in all the models estimated, two lags are enough to avoid autocorrelation problems and to capture the effects of dynamics following the Hannan and Quinn and Schwarz criterion.

23 To account for the aforementioned shocks experienced by the Chinese economy and to guarantee the normality of residuals and the stability of the parameters estimated, we have included two shift dummies restricted to the cointegration space (1970 and 1985) and two unrestricted permanent dummies (1976 and 1989), which take the form of $(0,0,0,1,1,1)$ and $(0,0,1,0,0,0)$ respectively. The criterion to include an unrestricted permanent dummy was $\left(\left|\hat{\varepsilon}_{1, t}\right|>3.3 \hat{\sigma}_{\varepsilon}\right)$. The dummies restricted to the cointegration space were identified according with the set of stability test and the difference with the unrestricted ones is that we allow for breaks in the determination of the trace test and therefore shifts in the long-run relations. For further details on the impact of deterministic components in the VAR Model, and the determination of the dummies according with the stability tests, see Juselius (2007). Additionally, the possibility of a structural break in 1978 was also tested, although it was not significant. A similar result was found by Kwant et al. (1999). 
Thus, once the residuals satisfy the assumptions of the VAR model and we have the well-specified model, we can find the possible long-run relationships by carrying out a trace test. However, this is not the only information available to check the rank of the long-run matrix - we also have the roots of companion matrix, the significance of alpha coefficients, and the graphics of the cointegrated vectors, among other relevant information. To save space in this paper, we focused on the trace test and the roots of companion matrix to check that, for the rank which was selected, the roots of the companion matrix are less than unity. This enabled us to find the stationary long-run relations which are reported in the Appendix. ${ }^{24}$ The procedure starts by investigating the null hypothesis $r=0$ and if it is rejected, we analyse $r=1$ until the null hypothesis is no longer rejected. We concluded that in all models estimated in this paper it is possible to find two long-run relationships.

Once we had chosen the rank of the long-run matrix as being equal to two, the variables were tested for weak exogeneity. The weak exogeneity test ${ }^{25}$ suggested that labour productivity or output (depending on each specification), together with equipment investment, are the only endogenous variables in all the specifications considered. The remaining variables considered in the paper are weakly exogenous, that is to say, they influenced the long-run stochastic path of the other variables in the system while at the same time they are not influenced by them. This result leaves the debate on the causality between equipment investment and productivity wide open. ${ }^{26}$

\section{Empirical Relations}

\section{a) Long-Run Structure}

After the specification of the model, structural hypotheses on the non-significant coefficients of each cointegrated vector are imposed until the most irreducible form is reached, with the aim of obtaining consistent coefficients in our estimation and achieving economic interpretation of our long-run relations. The general linear hypothesis on $\beta$ can be tested in the form:

$$
\mathcal{H}_{\beta}: \beta=\left(\mathrm{H}_{1} \varphi_{1}, \ldots, \mathrm{H}_{\mathrm{i}} \varphi_{\mathrm{i}}\right)
$$

where $\mathrm{H}_{\mathrm{i}}\left(\mathrm{p} x\left(\mathrm{p}-\mathrm{m}_{\mathrm{i}}\right)\right)$ imposes $\mathrm{m}_{\mathrm{i}}$ restrictions on $\beta_{\mathrm{i}}$ and $\varphi_{\mathrm{i}}\left(\left(\mathrm{p}-\mathrm{m}_{\mathrm{i}}\right) x 1\right)$ consists of $\mathrm{p}-\mathrm{m}_{\mathrm{i}}$ freely varying parameters. The LR test of the hypothesis is asymptotically distributed as $\chi^{2}$. The results of

\footnotetext{
${ }^{24}$ See Tables A2 to A8 in the Appendix. The remaining tests are available from the authors upon request.

${ }^{25}$ See Table A9 in the Appendix.

${ }^{26}$ See Blomström et al. (1996) and Temple (1998).
} 
the long-run relations we identified are reported in Table 1-3. In all cases the first cointegrated vector is normalized in output or labour productivity, while the second is normalized in equipment investment. They are expressed as an error correction mechanism or, in other words, as a deviation from the steady state.

We will now go on to outline our main results on the long-run relationships and they are discussed in detail below. In Table 1 we present the coefficients estimated for the base models. The first cointegrated vector in each model describes how equipment investment, exports-to-GDP ratio and the real exchange rate account for labour productivity and output levels in the long run. On the other hand, the second cointegrated vector shows a significant and positive impact of R\&D expenditure on equipment investment. The stationarity of these relations cannot be rejected with a $p$-value of 0.097 for the productivity model and 0.617 in the output model. Furthermore and in accordance with the battery of stability tests, ${ }^{27}$ the concentrated version of the model seems reasonably stable and all coefficients show the expected signs and are significant.

\section{(INSERT TABLE 1 NEAR HERE)}

To address the robustness of these results, first we included human capital, proxied by per capita years of schooling. The assumption is that people with a better education are a good indicator of more skilled and more productive workers. It is expected that more highly skilled people would be more able to innovate, and also to facilitate the absorption and adaptation of the new technology embodied in equipment investment, thus also increasing output and labour productivity.

In Table 2 we present the coefficients estimated for the models augmented with human capital. Once again, we find two long-run relations in both the labour productivity and output models. The first two relations describe how the results found in our previous models remain unchanged with the inclusion of human capital. In addition, we find that human capital makes a positive contribution to output and labour productivity in the long run. Moreover, in both models we find robust evidence that innovation activities measured by R\&D expenditure also enhance equipment investment in the long run. The stationarity of these relationships is not rejected, and thus the restrictions imposed were accepted by the data with a $p$-value of 0.336 and 0.391 , for the 
output and labour productivity models respectively.

(INSERT TABLE 2 NEAR HERE)

Finally, we took into account the role of infrastructures in this context. First, we tested the effect of the length of railways and highways in operation in these models; however, we did not find any empirical evidence to show that these two indicators affected output and labour productivity in the long run. ${ }^{28}$ We then took the other two indicators of infrastructures mentioned above, namely passenger-km of highways and passenger-km of railways. These indicators are associated with both infrastructure investment and demand.

\section{(INSERT TABLE 3 NEAR HERE)}

In these new estimations we also find two long-run relations in the output and labour productivity models. In all models, the first relation describes how these new indicators of infrastructures account for output or productivity in the long run. Although we only found evidence of the positive effect of rail in the labour productivity model, both indicators are significant in the output model. In addition, our results regarding equipment investment and exports remain unchanged with the introduction of infrastructures, thereby showing the robustness of our findings. The second long-run relationship found in both models is similar to that of previous estimates. All the restrictions in the labour productivity model were accepted with a $p$ value of 0.05 when rail was included. In the output model, all the restrictions were accepted with a $p$-value of 0.192 and 0.157 , respectively, when the rail and high variables were examined. These results are also relevant for the Chinese economy, because during the pre-reform period most infrastructure investment projects were finished and more investment was made than was actually required. Since the seventies, however, a vast increase in demand on the transportation system has taken place with a modest increase in new investments in infrastructures and this can only be accounted for by a more efficient use of the current transportation system (Bramall, 2000).

\footnotetext{
${ }^{27}$ Available upon request for all models estimated.

${ }^{28}$ These results are available upon request from the authors.
} 


\section{b) Dynamics of the models}

The procedure followed in order to identify the short-run dynamics, given the known long-run economic relations, starts with the most parsimonious model and it is reduced by sequentially imposing restrictions equal to zero on the non-significant coefficients until the most irreducible form is reached. Then, when the dynamics have been identified, it is possible to interpret the coefficient of the error correction mechanism $(\mathrm{ecm})$ as the speed of adjustment towards equilibrium. This coefficient has to be negative and significant if it is to be interpreted in economic terms. In addition, the first differences in the variables show the short-run effects on the endogenous variables that were considered. Furthermore, the direction of the causality (in the Grangerian sense) among the variables considered in each long-run relation can be tested by means of the significance of the coefficient of the error correction model $(\mathrm{ecm})$ in the dynamics of the models estimated.

(INSERT TABLE 4 NEAR HERE)

Table 4 reports the dynamics of the base models. The labour productivity equation is errorcorrecting with the two cointegrated vectors found in the productivity model $\left(\mathrm{ecm}_{1}\right.$ and $\left.\mathrm{ecm}_{2}\right)$. The alpha coefficient of the first long-run relationship, $\mathrm{ecm}_{1}$, shows that the adjustment towards equilibrium is approximately a year and a half, while the alpha of the second relationship, $\mathrm{ecm}_{2}$, shows that when investment is below its steady state, labour productivity undergoes a slight decrease. ${ }^{29}$ Thus, given that equipment investment enters in $\mathrm{ecm}_{1}$ the long-run relationship between labour productivity and equipment investment is empirically established. In addition, the estimated coefficients for the error correction mechanisms in the productivity model also suggest that equipment investment has a positive impact on the long-run level as well as on the growth rate of labour productivity. For instance, let us consider a small positive increase in equipment investment $(\Delta$ equip $>0)$ assuming the initial long-run equilibrium; this would make $\mathrm{ecm}_{1}$ negative by the negative coefficient on equipment investment in the first cointegrating relationship and hence implies a positive change in labour productivity. In the dynamics we find that labour productivity, $R \& D$ expenditure and the real exchange rate positively affect the labour productivity

\footnotetext{
${ }^{29}$ The rapid adjustment towards the steady state is an indication of the stationarity of these relations.
} 
equation, while the net effect of exports is negative in the short run. On the other hand, the equipment investment equation is error-correcting with the second cointegrated vector found in this model. The alpha coefficient indicates that the adjustment towards equilibrium takes place in approximately less than a year. In the short run, we find that R\&D expenditure and the lag of equipment investment have a positive effect on equipment investment. The positive effect of the lag of equipment investment indicates the existence of a significant inertia in equipment investment, which is indeed consistent with certain characteristics of a socialist and bureaucratically coordinated economy (Sun, 1998).

The output equation is error-correcting with the first cointegrated vector found in the output model and it adjusts towards equilibrium in almost seven months $\left(\mathrm{ecm}_{1}\right)$, while output increases when the equipment investment is above its steady state $\left(\mathrm{ecm}_{2}\right)$. In addition, we find that $\mathrm{R} \& \mathrm{D}$ expenditure and the lag of output have a positive effect on the output growth equation. Moreover, the net effect of exports is positive in this equation. The equipment investment equation does not exhibit significant equilibrium correction.

The positive effect of equipment investment in the first two long-run relations of each model $\left(\mathrm{ecm}_{1}\right)$ are in agreement with the findings of De Long and Summers (1991 and 1992), who highlighted the significant role of equipment investment among the components of capital accumulation. They also pointed to the probable existence of a link between embodied technology and capital goods in the endogenous growth theory. Equipment investment cannot be excluded from the long-run relationships in any of our cases, since a restriction equal to zero on the equipment investment coefficient is not accepted in any case by the data. ${ }^{30}$ In addition, in both models, not only does equipment investment enhance output and productivity in the long run, but the direction of the causality runs from equipment investment to output and labour productivity.

Thus, everything seems to indicate that China's strategy of acquiring advanced technology from abroad has had positive effects on output and productivity. The Chinese strategy has focused on promoting imports of capital and intermediate goods for those production processes which it cannot produce itself. These types of goods that are imported from developed countries are expected to have an embodied technological progress that is also relatively cheaper, thus boosting

\footnotetext{
${ }^{30}$ In the labour productivity model the restriction equal to zero on the equipment investment coefficient is distributed as $\chi^{2}(7)=20.55$ with a $p$-value of 0.004 , and in consequence is rejected, and for the output model $\chi^{2}(7)=17.03$ with a $p$-value of 0.017 . For the sake of simplicity, we only show the tests for the base model of labour productivity and output. The remaining tests are available upon request.
} 
both capital accumulation and its efficiency. ${ }^{31}$

An interesting result is that $R \& D$ expenditure in the long run stimulates equipment investment in both models. This is consistent with Howitt and Aghion (1998) and with Howitt (2000), who argued that capital accumulation should be complementary with innovation activities, both of which play a significant role in accounting for labour productivity and output in the long run.

In addition, and in line with other studies, ${ }^{32}$ we found that exports and competitiveness (measured by the real exchange rate) positively affect labour productivity and output in the long run. The role played by exports is consistent with the export-led growth hypothesis. ${ }^{33}$ In our case, the direction of the causality between output/productivity and exports is unidirectional; thus, in contrast to other works we did not find any evidence of bidirectional causality. In fact, in our case this result is not possible because exports become a weakly exogenous variable, and therefore they affect output and labour productivity but they are not affected by the other variables considered in this study. Furthermore, we found a positive effect of competitiveness on output and productivity, that is, the depreciation of the real exchange rate leads output and labour productivity in the long run. This result is in agreement with Gala (2008), who argued that competitive real exchange rates have been a key factor in fostering exports and growth in developing economies. It is also more specifically in line with the results found by Rodrik (2007) for the case of China, which indicate that the undervaluation of the Chinese currency has played a relevant role in driving economic growth.

Together, the fact that exports exogenously stimulated economic activity (that is to say, export-led growth) and the simultaneous depreciation of the real exchange rate could apparently be inconsistent. Yang (2008) emphasizes that the expansion of exports and output, in the case of export-led growth, should be accompanied by an appreciation of the real exchange rate. Nonetheless, this apparent inconsistency could be explained by the following two facts. First, it may be due to the existence of improvements in productivity which could have offset the tendency to appreciation of the real exchange rate and, second, because the undervaluation of Chinese currency has been employed as an additional policy mechanism to promote export expansion (Rodrik, 2007; Gala, 2008).

\footnotetext{
${ }^{31}$ See Lee (1995).

${ }^{32}$ See Shan and Sun (1998), Liu et al. (1997 and 2002).

${ }^{33}$ In the period 1962-1977 exports grew at an average rate of $8.15 \%$, while the average GDP growth rate was $7.04 \%$. This difference was higher in the post-reform period (1978-2004), with an
} 
Finally, in Tables 5 and 6 we report the dynamics of the models that have been augmented with human capital and infrastructures, respectively; their interpretation, regarding the adjustment towards equilibrium, is similar to the case of the base models.

\section{(INSERT TABLES 5 AND 6 NEAR HERE)}

These findings show that, even when we control our estimates for other relevant factors such as human capital or infrastructures, we can conclude that equipment investment and foreign trade polices have played a significant role in Chinese development over the last four decades. Of course, these same results suggest that investment and exports are not the only determinants of output and productivity in the long run, but human capital and the efficient use of infrastructures are also significant factors in determining the steady state of these variables. The empirical results are especially relevant in the case of human capital, because it seems that there is some degree of complementarity between equipment investment and the level of education in China. These findings are consistent with the relevant empirical literature mentioned before. Finally, in our model, R\&D expenditure continues to be the only non-deterministic factor that stimulates equipment investment in the long run: no direct influence of infrastructures or human capital on that relationship was detected.

\section{Further Comments and Conclusions}

De Long and Summers $(1991,1992)$ emphasized the strong association between equipment investment and economic growth, especially in the case of developing countries that are not able to produce this type of goods themselves. These countries have to acquire most of their investment in equipment through imports from advanced R\&D-intensive countries. Embodied technological progress is expected to exist in these types of goods and to cause long-run growth. Nonetheless, equipment investment is related with other important determinants of output and labour productivity such as human capital, infrastructures, R\&D expenditure and openness, among others, which could affect economic growth.

In this paper, we have analysed the role played by equipment investment as a determinant of output and labour productivity in the short and long run in China for the period 1964-2004. In

average growth rate of exports and GDP of $19.54 \%$ and $9.52 \%$, respectively. For a detailed discussion on the role played by export-led growth in China, see Bramall (2000). 
addition, we have assessed the robustness of the positive relationship between equipment investment and both output and productivity allowing for other relevant sources of economic growth, such as R\&D expenditure, human capital, exports and infrastructures. Our findings suggest that equipment investment and exports are relevant factors to account for output and labour productivity in the long run, even after controlling for other sources of long-run growth in China for the period considered. Moreover, we found that the direction of the causality in all the models estimated runs from equipment investment and exports to output and labour productivity in the long run. Furthermore, when human capital and infrastructures are included, we found that these factors also have a positive effect on labour productivity and output in the long run. A common result in all the models estimated is the positive effect of R\&D expenditure on equipment investment in the long run. Consequently, it seems that both capital accumulation and technical changes are significant for growth in the Chinese economy. Firstly, the fact that equipment investment, exports and human capital have had long-run effects on output and productivity is consistent with the existence of embodied technological progress, knowledge and different kinds of positive externalities. Secondly, a significant effect of $R \& D$ expenditure on equipment investment is more plausible in some Schumpeterian versions of endogenous growth theory than in traditional models of growth, especially for the case of China, where most of the equipment investment is imported from developed countries that are intensive in R\&D activities. In this type of models, capital accumulation and knowledge are complementary and play a critical role in the transition to long-run growth. Capital accumulation required new and advanced technology embodied in new investments, given the diminished returns on capital, and at the same time new technologies need investments to implement them in the production process. Furthermore, the positive effect of human capital on labour productivity and output in the long run is probably related with other forms of technology transmission, like absorption, adaptation or new inventions which cause long-run growth. Finally, the diffusion of technology through international trade is one of the additional relevant mechanisms to promote labour productivity and output in the long run.

Although equipment investment, $R \& D$ expenditure, exports, human capital and infrastructures seem to have played an undeniably important role throughout the period under study, there are deep structural problems that may be a source of increasing constraints in the future and we have to qualify our findings. First, the various reforms implemented to facilitate the integration of China 
into the international markets have made it one the largest traders in the world and everything seems to indicate that this strategy has given good results. However, high investment rates, in particular in equipment investment, have intensified its dependence on imported capital and intermediate goods, thus weakening internal demand and increasing foreign dependence. This, in turn, has increased the need for high levels of exports in order to prevent foreign constraint. Hover, But this intense export promotion policy has also been questioned in the literature. Critics argue that it is unsustainable because there is not enough foreign demand to absorb these increasing volumes of exports. Others, however, support this policy, given that the majority of Chinese exports are goods that are processed with imported materials and if these imports are deducted, then even after the opening up of the Chinese economy it is still far behind the countries with the highest levels of trade.

Second, for most of the period considered investment grew faster than GDP, and the high growth rate of investment for long periods of time has also been questioned in the literature. On the one hand, doubts arise because the effect of high savings and investment rates in China is that consumption still remains at very low levels, and this has implies of the the internal demand is weak and creates the aforementioned dependence on the externall sector, ats obvious implications in terms of welfare. And, on the other hand, there is a risk of overinvestment and the consequent reduction in the productivity of capital. Consequently, this seenario will affect the pace at which technologieal innovation is incorporated into the stock of installed eapital and weaken the forees that offset the tendency towards diminishing returns in the acemulation of eapital. However, it is well known that this investment is mainly located in the coastal provinces. Thus, this effect could not work if investment were redistributed across those provinces that have lower levels of capital accumulation, like the central and western provinces.

From another point of view, we have found that human and innovation activities exert a positive influence on output and productivity, that but these two key factors are relatively scarce in the Chinese economy, both in absolute terms and when they are compared with developed countries. Indeed, as it is argued in Heckman (2005) is evident that the Chinese government has tended to promote physical capital over human capital throughout the considered period. For example, in 1995, China atl avels of avernment, spent about $2.5 \%$ of its GDP on investment schooling, whereas for the case of the United States this figure was a 5.4\%, for Japan a 
However, roughly $30 \%$ of Chinese GDP was devoted to physical capital, in contrast with a $17 \%$ for the case of the United States. Similar trends are possible to observe with regards to innovation activities. In 1995, The United States and Japan were in the top ranking among the countries that invest more in innovation measured by patents (around a 37\% of global share of R\&D and 15\% respectively), whereas China, India and Brazil represented around 2.5\%. By 2006, international tandseape for innovation has-seen the emergenee-of new and important players-steh as China that undergone a dramatic increase in R\&D expenditure since early 2000 up to $10 \%$ (DE QUÉ SOBRE QUÉ?), although this figure is still far away from those registered by developed countries. ${ }^{34}$ Thus, $^{3}$ there is still considerable scope to economic policies that stimulate technological innovation and human capital accumulation to strengthening domestic productivity, rebalancing the Chinese sources of growth and ensuring a more sustained economic development Eeomie өn the promotion of human eapital, which is the essene- of innovation are the key tostrengthening domestic demand and thus maintaining a more balanced sources of growth and ensure-sustained economic development in the future in China.

\section{Acknowledgements}

We are grateful to Hong Li, Sharon Xiaowen Lin, Guy Liu and John Weiss and the participants at the 19th Annual Conference of the Chinese Economic Association at the University of Cambridge, the participants of The Chinese Economists Society 2008 at the Nankai University in Tianjin, and the participants of the European Trade Study Group 2008 at the University of Warsaw, for helpful comments and suggestions. The authors gratefully acknowledge financial support from the Spanish Ministry of Science and Innovation, (project ECO2008-06057/ECON) and Generalitat Valenciana (BFPI06/442 and Prometeo/2009/068). The usual disclaimer applies.

\section{References}

Aghion, P. and Howitt, P., (1992). A model of Growth through creative destruction. Econometrica 60, 323-351

Aghion, P. Howitt, P., (1999). Endogenous Growth Theory. MIT Press, Cambridge, MA.

Aghion, P. and Howitt, P., (2007). Capital, innovations and growth accounting. Oxford Review of Economic Policy 23, 79-93.

An, G. and Iyigun, M.F., (2004). The export technology content, learning by doing and specialization in foreign trade. Journal of International Economics 64, 465-483.

Aschauer, D.A., (1988). Government Spending and the "falling rate" of profit. Journal of Economic Perspectives 12 (May), 11-17

Aschauer, D. A., (1989). Is public expenditure productive? Journal of Monetary Economics $23,177-200$

\section{Source: OECD}


Auerbach A.J., Hassett K.A. and Oliner S.D., (1994). Reassessing the social returns to equipment investment. Quarterly Journal of Economics 109, 789-802.

Bai, C., Hsieh, C. and Qian, Y. (2006). The Return to Capital in China. NBER Working Paper No. 12755

Baldwin, R. E., (2003). Openness and Growth: What's the empirical relationship? NBER Working Paper No. 9578

Barro, R., (2001). Human Capital and Growth. The American Economic Review 91, 12-17.

Benhabib, J. and Spiegel, M. M., (1994). The Role of Human Capital in Economic Development: Evidence from Aggregate Cross-Country and Regional U.S. Data. Journal of Monetary Economics, 34, 2, 143-173.

Berglas, E., (1965). Investment and Technological change. The Journal of Political Economy 73, 173-180.

Bils, M. and Klenow, P., (2000). Does schooling cause growth? American Economic Review 90, 1160-1183

Blomström, M., Lipsey, R.E., and Zejan, M. (1996). Is Fixed Investment the Key to Economic Growth? Quarterly Journal of Economics 111, 269-276.

Boileau, M., (2002). Trade in capital goods and investment-specific technical change. Journal of Economic Dynamics and Control 26, 963-984.

Borensztein, E. and Ostry, J.D. (1996). Accounting for China growth performance. American Economic Review 86, 225-228

Borensztein, E., De Gregorio, J. and Lee, J-W., (1998). How does foreign direct investment affect economic growth? Journal of International Economics 45, 115-135.

Bramall, C., (2000). Sources of Chinese Economic Growth 1978-1996. Studies on Contemporary China. Oxford University Press.

Caballe, J. and Santos, M. (1993). On Endogenous Growth with Physical and Human Capital. The Journal of Political Economy 101, 1042-1067

Canning, D., Fay, M. and Perotti, R. (1994). Infrastructure and growth. In M. Baldassarri, L. Paganetto, \& E.S. Phelps (Eds), International differences in growth rates. Great Britain: The Macmillan Press.

Caselli, F. and Wilson, D.J., (2004). Importing technology. Journal of monetary Economics $51,1-32$.

Chow, G. (1987). Money and price determination in China. Journal of Comparative Economics 11, 319-333

Chow, G., (1993). Capital Formation and Economic Growth in China. The Quarterly Journal of Economics 108, 809-842

Chow, G., (2004). Knowing China. Singapore: World Scientific Publishing Co.

Chow, G. (2006). Are Chinese Statistics Reliable? Cesifo Economic Studies 52, 396-414

Chow, G. (2008). Another look at the rate of increase in TFP in China. Journal of Chinese Economic and Business Studies 6, 219-224

Chow, G. and Lin, A. (2002). Accounting for economic growth in Taiwan and mainland China: a comparative analysis. Journal of Comparative Economics 30, 507-530.

Chuang, Y., (1998). Learning by doing, the technology gap, and growth. International Economic Review 39, 697-721

Dellas, H. and Koubi, V., (2001). Industrial Employment, Investment Equipment, and Economic Growth. Economic Development and Cultural Change, University of Chicago Press 49, 867-881

De Long, J.B. and Summers, L.H., (1991). Equipment Investment and Economic Growth. The Quarterly Journal of Economics 106, 445-502

De Long J.B., Summers L.H and Abel A.B., (1992). Equipment Investment and Economic Growth: How strong is the nexus? Brookings Papers on Economic activity 1992, $157-$ 211

Démurger, S., (2001). Infrastructure Development and economic growth: An explanation for regional disparities in China? Journal of Comparative Economics 29, 95-117.

Devarajan, S. Vinaya, S. and Heng-Fu, Z., (1996). The composition of public expenditure and economic growth. Journal of Monetary Economics 37, 313-344. 
Eaton, J. and Kortum, S., (2001). Trade in capital goods. European Economic Review 45, 1195-1235.

Eisner R., (1991). Infrastructure and Regional economic performance. New England Economic Review, Federal Reserve Bank of Boston, September/October, 47-58.

Easterly W. and Rebelo S., (1993). Fiscal policy and economic growth. Journal of monetary Economics 32, 417-458.

Esfahani, H.S., (1991). Exports, Imports, and Economic Growth in Semi-Industrialized Countries. Journal of Development Economics 35, 93-116.

Ezaki, M. and Sun, L. (1999). Growth Accounting in China for National, Regional, and Provincial Economies: 1981-1995. Asian Economic Journal 13, 39-71

Fan, S. and Zhang, X., (2004). Infrastructure and regional economic development in rural China. China Economic Review 15, 203-214.

Feder, G. (1983). On exports and economic growth. Journal of Development Economics 12, $59-73$

Fernald, J. G., (1999). Roads to Prosperity? Assessing the link between pubic capital and productivity. The American Economic Review 89, 619-638

Flores, de Frutos, A. and Pereira, A., (1993). Public Capital and Aggregate Growth in the United States: Is Public Capital Productive? U. of California at San Diego Discussion Paper 93-31

Frankel, J. A. and Romer, D., (1999). Does Trade Cause Growth? The American Economic Review 89, 379-394

Gala, P. (2008). Real Exchange Rate Levels and Economic Development: Theoretical Analysis and Empirical Evidence. Cambridge Journal of Economics 32, 273-288

Garcia-Mila, T. McGuire, T. J. and Porter, R.H., (1996). The effect of public capital in statelevel production functions reconsidered. The Review of Economics and Statistics 78, 177-180.

Greenwood, J., Hercowitz, Z. and Krusell, P., (1997). Long-run implications of investmentspecific technological change. American economic review 87, 342-362.

Griliches, Z. and Jorgenson, D.W., (1966). Sources of Measured productivity Change: Capital input. The American Economic Review 56, 50-61.

Grossman, G.M. and Helpman, E., (1991). Innovation and Growth in the Global Economy Cambridge, Massachusetts, MIT Press.

Heckman, J., (2005). China's Human Capital Investment. China Economic Review 16, 50-70

Helpman, E., (1988). Growth Technological Progress and Trade. Empirica Austrian Economic Papers 5, 5-25.

Hendricks, L., (2000). Equipment investment and growth in developing countries. Journal of Development Economics 61, 335-364.

Herrerias, MJ. and Orts, V., (2009). Openness and Productivity in China. In Z. Wu (ed.): China in the World Economy, Chapter 10. pp.197-209 Routledge.

Herrerias, MJ. and Orts, V., (2010) Is the Export-led Growth Hypothesis enough to account for China's growth?. China \& World Economy, Forthcoming

Holz, C.A. (2005). OECD - China Governance Project: The Institutional Arrangements for the Production of Statistics", OECD Statistics Working Papers, 2005/1, OECD Publishing.

Holz, C., (2006). Measuring Chinese Productivity Growth 1952-2005. (July 22, 2006). Available at http://ihome.ust.hk/\%7Esocholz/China-productivity-measures-web22July06.pdf

Holtz-Eakin, D., (1994). Public-sector capital and the productivity puzzle. The Review of Economics and Statistics 76, 12-21.

Howitt, P., (2000). Endogenous Growth and Cross-Country Income Differences. American Economic Review, 90, 829- 846

Howitt, P. and Aghion, P., (1998). Capital Accumulation and Innovation as Complementary Factors in Long-Run Growth. Journal of Economic Growth 3, 111-130 
Hsiao, .S.T. and Hsiao, W., (2006). FDI, exports, and GDP in East and Southeast AsiaPanel data versus time-series causality analyses. Journal of Asian Economics 17 (6), 1082-1106

Hu, Z. L., and Khan, M. S. (1996). Why is China growing so fast? IMF Staff Papers. Washington, DC: International Monetary Fund. WP No.96/75

Hulten, C.R., (1992). Growth accounting when technical change is embodied in capital. American Economic Review 82, 964-980.

Hulten, C. R. Bennathan, E. and Srinivasan, S., (2006). Infrastructure, externalities and economic development: A study of Indian manufacturing industry. The World Bank Economic Review 20, 291-308.

Johansen, S., (1988). Statistical Analysis of Cointegration Vectors. Journal of Economic Dynamics and Control 12, 231-254

Johansen, S. And Juselius, K., (1990). Maximum Likelihood Estimation and inference on cointegration-with Applications to the Demand for money. Oxford Bulletin of Economics and Statistics 52, 169-210.

Johansen, S. and Juselius, K., (1994). Identification of the Long-run and the Short-run structure. An application to the ISLM model. Journal of Econometrics 63, 7-36

Johansen, S., (1995). Likelihood-Based inference in cointegrated vector auto-regressive models. Advance Texts in Econometrics. Oxford University Press

Juselius, K., (2007). The cointegrated VAR model: Econometric methodology and macroeconomics applications. Oxford University Press

Juselius, K. and MacDonald, R., (2004). International parity relationships between the USA and Japan. Japan and the World economy 16, 17-34.

Juselius, K. and MacDonald, R., (2000). International parity relationships between Germany and the United States: A joint Modelling approach. Working paper. Institute of Economics. University of Copenhagen

Kwan, C.C.A., Wu, Y. and Zhang, J., (1999). Fixed Investment and Economic Growth in China. Economics of planning 32, 67-79.

Lai, M., Peng, S. and Bao, Q., (2006). Technology spillovers, absorptive capacity and economic growth. China Economic Review 17, 300-320.

Lee, J.W., (1995). Capital goods imports and long-run growth. Journal of Development Economics 48, 91-110.

Levine, R. and Renelt, D., (1992). A sensitivity analysis of cross-country growth regressions. American Economic Review 82, 942-963.

Li, X. (2000). The Great Leap Forward, Economic Reforms, and the Unit Root Hypothesis: Testing for Breaking Trend Functions in China's GDP Data. Journal of Comparative Economics 28, 814-827

Liu, X., Song, H. and Romilly, P., (1997). An empirical investigation of the causal relationship between openness and economic growth in China. Applied Economics 29, 1679-86

Liu, X. Burridge, P. and Sinclair, P.J.N., (2002). Relationships between economic growth, foreign direct investment and trade: evidence from China. Applied Economics 34, 1433-1440.

Liu, Z., (2007). The external returns to education: Evidence from Chinese cities. Journal of Urban Economics 61, 542-564.

Lopez, R.A., (2005). Trade and Growth: Reconciling the Macroeconomic and Microeconomic Evidence. Journal of Economic Surveys 19, 623-648

Lucas, R. E. JR., (1988). On the Mechanics of Economic Development. Journal of Monetary Economics, 22, 3-42.

Madsen, J.B., (2002). The causality between investment and economic growth. Economic Letters 74 (2), 157-163.

Melitz, M.J., (2003). The Impact of Trade on Intra-Industry Reallocations and Aggregate Industry Productivity, Econometrica 71, 1695-1725

Munnell, A.H., (1990a). Why has productivity growth declined? Productivity and public investment. New England Economic Review, (January/February), 3-22. 
Munnell, A.H., (1990b). How does public infrastructure affect regional economic performance? New England Economic Review, (September/October), 11-32.

Munnell, A.H., (1992). Policy Watch: Infrastructure Investment and economic growth. The Journal of Economic Perspectives 6, 189-198.

National Bureau of Statistic of China (2006). China Compendium of Statistics 1949-2004. China Statistics Press

Nelson, R. and Phelps, E., (1966). Investment in humans, technological diffusion, and economic growth. American Economic Review LVI, 69-75.

Nielsen, H., (2004). Cointegration analysis in the presence of outliers. Econometrics Journal 7, 249-271

Perkins, D. (1994). Completing China's move to the market. Journal of Economic Perspective 8, 23-46

Phylaktis, K. and Girardin, E. (2001). Foreign exchange markets in transition economies: China. Journal of Development Economics 64, 215-235

Qin, D., Cagas, A., Quising, P. and He, X. (2005). How much Does Investment Drive Economic Growth in China? Queen Mary University of London, Department of economics, working paper No 545.

Riezman, R.G., Summers, P.M. and Whiteman, C.H., (1996). The engine of Growth or its handmaiden? A time series assessment of export-led growth. Empirical Economics. 21, 77-113.

Rivera-Batiz, L.A. and Romer, P.M., (1991). Economic Integration and Endogenous Growth. Quarterly Journal of Economics, 106, 531-556.

Rodriguez, F. and Rodrik, D., (2001). Trade policy and economic growth: A skeptic's guide to the cross-national evidence in B.S. Bernake and K. Rogoff (eds.) NBER Macroeconomics Annual 2000, The MIT press Cambridge.

Rodrik, D., (1999). New Global Economics and Developing Countries: Making the Openness Work. Policy Essay No. 24. Washington D.C. Overseas Development Council. Johns Hopkins University Press, Baltimore.

Rodrik, D. (2007). The Real Exchange Rate and Economic Growth: Theory and Evidence. Undervaluation is good for growth, but why? Working paper. Harvard University.

Röller, L.H. and Waverman, L., (2001). Telecommunications Infrastructure and economic development: A simultaneous approach. The American Economic Review 91, 909-923

Romer, P. (1986). Increasing Returns and Long-Run Growth. The Journal of Economics Perspectives 8, 3-22

Romer, P., (1990). Endogenous Technological Change. Journal of Political Economy 98, 71102

Shan, J. and Sun, F., (1998). On the export-led growth hypothesis: the econometric evidence from China. Applied Economics 30, 1055-1065

Sun, L. (1998). Estimating investment function based in cointegration: The case of China. Journal of Comparative Economics 26, 175-191

Sianesi, B. and Reenen, J.V., (2003). The returns to education: Macroeconomics. Journal of Economic Surveys 17, 157-200.

Tatom, J.A. (1993). Is an infrastructure crisis lowering the nation's productivity?, Review, Federal Reserve Bank of St. Louis, issue Nov, 3-21

Temple, J. (1998). Equipment investment and the Solow model. Oxford Economic Papers $50,39-62$.

Temple, J. and Voth, H., (1998). Human capital, equipment investment, and industrialization. European Economic Review 42, 1343-1362.

Uzawa, H., (1965). Optimum Technical Change in an Aggregative Model of Economic Growth. International Economic Review 6, 18-31.

Wang, Y. and Yao, Y., (2003). Sources of China's economic growth 1952-1999: incorporating human capital accumulation" China Economic Review 14, 32-52.

Yang, J. (2008). An Analysis of So-Called Export-led Growth. IMF Working Paper $W P / 08 / 220$ 
Yao, S. (2000). How important is agriculture in China's economic growth? Oxford Development Studies 28, 33-50.

Young, A., (1991). Learning by doing and the dynamics effects of international trade. The Quarterly Journal of Economics 106, 369-405

Young, A. (2003). Gold into base metals: productivity growth in the people's Republic of China during the reform period. Journal of Political Economic 111, 1220-1261

Yu, Q., (1998). Capital investment, international trade and economic growth in China: Evidence in the 1980-90s. China Economic Review 9, 73-84.

Yusuf, S., (1994). China's Macroeconomic Performance and Management During Transition. The Journal of Economic Perspectives 8, 71-92 


\section{List of Tables}

Table 1: Base Models ${ }^{35,36}$

\begin{tabular}{|c|c|c|c|c|c|}
\hline \multicolumn{6}{|c|}{ Productivity Model } \\
\hline & prod & equip & $r d$ & $x / g d p$ & rer \\
\hline $\mathrm{ecm}_{1 \mathrm{t}}$ & 1 & $\begin{array}{c}-0.21 \\
{[-7.85]}\end{array}$ & 0 & $\begin{array}{c}-4.79 \\
{[-9.45]}\end{array}$ & $\begin{array}{c}-1.11 \\
{[-4.95]}\end{array}$ \\
\hline $\mathrm{ecm}_{2 \mathrm{t}}$ & 0 & 1 & $\begin{array}{c}-1.41 \\
{[-13.78]}\end{array}$ & 0 & 0 \\
\hline \multicolumn{6}{|c|}{ Output Model } \\
\hline & $g d p$ & equip & $r d$ & $x / g d p$ & rer \\
\hline $\mathrm{ecm}_{1 \mathrm{t}}$ & 1 & $\begin{array}{c}-0.13 \\
{[-2.92]}\end{array}$ & 0 & $\begin{array}{c}-1.50 \\
{[-2.83]}\end{array}$ & $\begin{array}{c}-1.25 \\
{[-4.57]}\end{array}$ \\
\hline $\mathrm{ecm}_{2 \mathrm{t}}$ & 0 & 1 & $\begin{array}{c}-1.39 \\
{[-13.99]}\end{array}$ & 0 & 0 \\
\hline
\end{tabular}

Table 2: Models Augmented with Human Capital

\begin{tabular}{|c|c|c|c|c|c|c|}
\hline \multicolumn{7}{|c|}{ Productivity Model } \\
\hline & prod & equip & $r d$ & $x / g d p$ & rer & $H c$ \\
\hline $\mathrm{ecm}_{1 \mathrm{t}}$ & 1 & $\begin{array}{c}-0.17 \\
{[-4.27]}\end{array}$ & 0 & $\begin{array}{c}-4.06 \\
{[-5.10]}\end{array}$ & $\begin{array}{c}-1.95 \\
{[-6.37]}\end{array}$ & $\begin{array}{c}-0.62 \\
{[-2.57]}\end{array}$ \\
\hline $\mathrm{ecm}_{2 \mathrm{t}}$ & 0 & 1 & $\begin{array}{c}-1.06 \\
{[-3.99]}\end{array}$ & 0 & 0 & 0 \\
\hline \multicolumn{7}{|c|}{ Output Model } \\
\hline & $g d p$ & equip & $r d$ & $x / g d p$ & rer & $h c$ \\
\hline $\mathrm{ecm}_{1 \mathrm{t}}$ & 1 & $\begin{array}{c}-0.25 \\
{[-7.65]}\end{array}$ & 0 & $\begin{array}{c}-2.75 \\
{[-3.61]}\end{array}$ & $\begin{array}{c}-2.82 \\
{[-9.55]}\end{array}$ & $\begin{array}{c}-0.70 \\
{[-3.05]}\end{array}$ \\
\hline $\mathrm{ecm}_{2 \mathrm{t}}$ & 0 & 1 & $\begin{array}{c}-1.39 \\
{[-12.44]}\end{array}$ & 0 & 0 & 0 \\
\hline
\end{tabular}

Table 3: Models Augmented with Infrastructures

\begin{tabular}{|c|c|c|c|c|c|c|c|c|}
\hline & \multicolumn{8}{|c|}{ Productivity Model } \\
\hline & & prod & equip & $r d$ & $x / g d p$ & rer & & \\
\hline & $\mathrm{ecm}_{1 \mathrm{t}}$ & 1 & $\begin{array}{c}-0.13 \\
{[-5.31]}\end{array}$ & 0 & $\begin{array}{c}-5.94 \\
{[-16.26]}\end{array}$ & 0 & & \\
\hline & $\mathrm{ecm}_{2 \mathrm{t}}$ & 0 & {$[-$} & $\begin{array}{l}-1.40 \\
-14.73]\end{array}$ & $\begin{array}{lll} & \end{array}$ & 0 & & \\
\hline & & & Out & tput Model & & & & \\
\hline & $g d p$ & equip & $r d$ & $x / g d p$ & rer & & igh & rail \\
\hline $\mathrm{ecm}_{1 \mathrm{t}}$ & 1 & $\begin{array}{c}-0.20 \\
{[-5.88]}\end{array}$ & 0 & $\begin{array}{c}-3.98 \\
{[-6.39]}\end{array}$ & $\begin{array}{c}-1.04 \\
{[-2.80]}\end{array}$ & & & $\begin{array}{c}-0.45 \\
{[-3.61]}\end{array}$ \\
\hline $\mathrm{ecm}_{2 \mathrm{t}}$ & 0 & 1 & $\begin{array}{c}-1.44 \\
{[-14.93]}\end{array}$ & 0 & 0 & & & 0 \\
\hline $\mathrm{ecm}_{1 \mathrm{t}}$ & 1 & $\begin{array}{c}-0.18 \\
{[-3.33]}\end{array}$ & 0 & $\begin{array}{c}-4.99 \\
{[-8.11]}\end{array}$ & 0 & & $\begin{array}{l}.83 \\
.68]\end{array}$ & \\
\hline $\mathrm{ecm}_{2 \mathrm{t}}$ & 0 & 1 & $\begin{array}{c}-0.89 \\
{[-3.35]}\end{array}$ & 0 & 0 & & 0 & \\
\hline
\end{tabular}

\footnotetext{
${ }^{35}$ We show only the coefficients of the stochastic variables; the deterministic components are available upon request.

${ }^{36}$ The difference in the size of the coefficient of exports compared to that of equipment investment can probably be explained by the fact that is a ratio, while the others are in logs.
} 
Table 4: Base Models:

\begin{tabular}{|c|c|c|c|c|c|c|c|c|c|}
\hline \multicolumn{10}{|c|}{ Productivity Model } \\
\hline & $\Delta \operatorname{prod}_{t-1}$ & $\Delta$ equip $_{\mathrm{t}-1}$ & $\Delta \operatorname{rer}_{\mathrm{t}-1}$ & $\Delta \mathrm{rd}_{\mathrm{t}}$ & $\Delta \mathrm{rd}_{\mathrm{t}-1}$ & $\Delta \mathrm{x} / \mathrm{gdp}$ & $\Delta \mathrm{x} / \mathrm{gdp}_{\mathrm{t}-1}$ & $\mathrm{ecm}_{1(\mathrm{t}-1)}$ & $\mathrm{ecm}_{2(\mathrm{t}-1)}$ \\
\hline$\Delta \operatorname{prod}_{\mathrm{t}}$ & $\begin{array}{c}0.33 \\
{[4.97]}\end{array}$ & 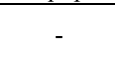 & $\begin{array}{c}0.14 \\
{[2.60]}\end{array}$ & $\begin{array}{c}0.21 \\
{[10.3]}\end{array}$ & $\begin{array}{c}0.04 \\
{[2.41]}\end{array}$ & $\begin{array}{c}0.26 \\
{[3.13]}\end{array}$ & $\begin{array}{c}-0.45 \\
{[-4.01]}\end{array}$ & $\begin{array}{l}\mathbf{- 0 . 5 9} \\
{[-7.09]}\end{array}$ & $\begin{array}{c}-\mathbf{- 0 . 1 0} \\
{[-3.89]}\end{array}$ \\
\hline$\Delta$ equip $_{\mathrm{t}}$ & - & $\begin{array}{c}0.32 \\
{[5.35]} \\
\end{array}$ & - & $\begin{array}{c}1.91 \\
{[9.95]}\end{array}$ & - & - & - & $x^{2}-5$ & $\begin{array}{l}-1.24 \\
{[-4.89]}\end{array}$ \\
\hline \multicolumn{10}{|c|}{$\begin{array}{l}\mathrm{ecm}_{1(\mathrm{t}-1)}=\text { prod }-0.21 \text { equip }-4.79 x / g d p-1.11 \text { rer } \\
\mathrm{ecm}_{2(\mathrm{t}-1)}=\text { equip }-1.41 \mathrm{rd}\end{array}$} \\
\hline \multicolumn{10}{|c|}{$\chi^{2}[16]=16.434[0.4231]$} \\
\hline \multicolumn{10}{|c|}{ Output Model } \\
\hline & $\Delta \mathrm{gdp}_{\mathrm{t}-1}$ & $\Delta$ equip $_{\mathrm{t}-1}$ & $\Delta$ rer $_{\mathrm{t}-1}$ & $\Delta \mathrm{rd}$ & $\Delta \mathrm{rd}_{\mathrm{t}-1}$ & $\Delta \mathrm{x} / \mathrm{gdp}$ & $\Delta \mathrm{x} / \mathrm{gdp}_{\mathrm{t}-1}$ & $\mathrm{ecm}_{1(\mathrm{t}-1)}$ & $\mathrm{ecm}_{2(\mathrm{t}-1)}$ \\
\hline$\Delta \mathrm{gdp}_{\mathrm{t}}$ & $\begin{array}{c}0.34 \\
{[6.54]}\end{array}$ & & - & $\begin{array}{c}0.21 \\
{[9.05]}\end{array}$ & - & $\begin{array}{c}0.21 \\
{[2.72]}\end{array}$ & $\begin{array}{c}-0.18 \\
{[-2.16]}\end{array}$ & $\begin{array}{c}\mathbf{- 1 . 7 8} \\
{[-9.80]}\end{array}$ & $\begin{array}{c}\mathbf{0 . 1 4} \\
{[3.69]}\end{array}$ \\
\hline$\Delta$ equip $_{\mathrm{t}}$ & - & $\begin{array}{c}0.28 \\
{[5.65]} \\
\end{array}$ & - & $\begin{array}{c}1.90 \\
{[9.78]}\end{array}$ & - & - & - & - & $\begin{array}{c}1.54 \\
{[4.68]}\end{array}$ \\
\hline \multicolumn{10}{|c|}{$\begin{array}{l}\mathrm{ecm}_{1(\mathrm{t}-1)}=\text { gdp -0.13equip }-1.50 x / g d p-1.25 \mathrm{rer} \\
\mathrm{ecm}_{2(\mathrm{t}-1)}=\text { equip }-1.39 \mathrm{rd}\end{array}$} \\
\hline$\chi^{2}[18]=2$ & $092[0.1$ & & & & & & & & \\
\hline
\end{tabular}

Table 5: Models Augmented with Human Capital

\begin{tabular}{|c|c|c|c|c|c|c|c|c|c|c|}
\hline \multicolumn{11}{|c|}{ Productivity Model } \\
\hline & $\Delta \operatorname{prod}_{\mathrm{t}-1}$ & $\Delta$ equip $_{\mathrm{t}-1}$ & $\Delta$ rer $_{\mathrm{t}-1}$ & $\Delta \mathrm{rd}_{\mathrm{t}}$ & $\Delta \mathrm{x} / \mathrm{gdp}_{\mathrm{t}}$ & $\Delta \mathrm{x} / \mathrm{gdp}_{\mathrm{t}-1}$ & $\Delta^{2} \mathrm{hc}_{\mathrm{t}}$ & $\Delta^{2} \mathrm{hc}_{\mathrm{t}-1}$ & $\mathrm{ecm}_{1[\mathrm{t}-1)}$ & $\mathrm{ecm}_{2[\mathrm{t}-1)}$ \\
\hline$\Delta \operatorname{prod}_{\mathrm{t}}$ & $1+21$ & $\begin{array}{c}0.09 \\
{[6.83]}\end{array}$ & {$[-1$} & $\begin{array}{c}0.15 \\
{[6.21]}\end{array}$ & $21 t$ & 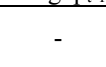 & $\begin{array}{c}0.09 \\
{[2.53]}\end{array}$ & $e_{1-1}$ & $\begin{array}{c}\mathbf{- 0 . 5 9} \\
{[-7.36]}\end{array}$ & $\begin{array}{c}-\mathbf{- 0 . 2 7} \\
{[-4.60]}\end{array}$ \\
\hline$\Delta$ equip $_{\mathrm{t}}$ & $\begin{array}{c}-2.82 \\
{[-4.31]}\end{array}$ & $\begin{array}{c}1.01 \\
{[6.93]}\end{array}$ & $\begin{array}{c}-1.13 \\
{[-2.49]}\end{array}$ & $\begin{array}{c}1.33 \\
{[6.14]}\end{array}$ & $\begin{array}{c}-2.24 \\
{[-3.35]}\end{array}$ & $\begin{array}{c}2.70 \\
{[3.02]}\end{array}$ & - & $\begin{array}{c}0.70 \\
{[2.24]}\end{array}$ & {$[-]^{2}$} & $\begin{array}{c}-2.80 \\
{[-5.69]}\end{array}$ \\
\hline $\begin{array}{l}e^{e c m_{1(t-1}} \\
\text { ecm } \\
2(t-1\end{array}$ & $\begin{array}{l}\text { prod-c }-1 \\
\text { equip- }\end{array}$ & $\begin{array}{l}\text { equip- } \\
\text { 6rd }\end{array}$ & $6 x / g d p$ & $1.95 \mathrm{re}$ & $0.62 h c$ & & & & & \\
\hline
\end{tabular}

\begin{tabular}{|c|c|c|c|c|c|c|c|c|c|c|c|}
\hline \multicolumn{12}{|c|}{ Output Model } \\
\hline & $\Delta \mathrm{gdp}_{\mathrm{t}-1}$ & $\Delta$ equip $_{\mathrm{t}-1}$ & $\Delta \mathrm{rer}_{\mathrm{t}}$ & $\Delta$ rer $_{\mathrm{t}-1}$ & $\Delta \mathrm{rd}_{\mathrm{t}}$ & $\Delta \mathrm{x} / \mathrm{gdp}_{\mathrm{t}}$ & $\Delta \mathrm{x} / \mathrm{gdp}_{\mathrm{t}-1}$ & $\Delta^{2} h c_{t}$ & $\Delta^{2} h c_{t-1}$ & $\mathrm{ecm}_{1[\mathrm{t}-1)}$ & $\mathrm{ecm}_{2[\mathrm{t}-1)}$ \\
\hline$\Delta \mathrm{gdp}_{\mathrm{t}}$ & - & $\begin{array}{c}0.04 \\
{[4.24]}\end{array}$ & - & 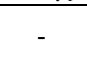 & $\begin{array}{c}0.20 \\
{[7.87]}\end{array}$ & 4. & $\begin{array}{c}-0.19 \\
{[-2.19]}\end{array}$ & - & 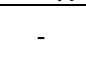 & $\begin{array}{c}\mathbf{- 0 . 7 3} \\
{[-10.5]}\end{array}$ & $\begin{array}{c}\mathbf{- 0 . 3 3} \\
{[-4.31]}\end{array}$ \\
\hline$\Delta$ equip $_{\mathrm{t}}$ & $\begin{array}{c}-1.40 \\
{[-2.85]}\end{array}$ & $\begin{array}{c}0.55 \\
{[6.06]} \\
\end{array}$ & $\begin{array}{c}-1.16 \\
{[-3.85]}\end{array}$ & - & $\begin{array}{c}1.70 \\
{[8.70]}\end{array}$ & - & - & - & $\begin{array}{c}1.01 \\
{[3.70]}\end{array}$ & - & $\begin{array}{c}\mathbf{3 . 0 9} \\
{[-5.20]}\end{array}$ \\
\hline \multicolumn{12}{|c|}{$\begin{array}{l}\mathrm{ecm}_{1(\mathrm{t}-1)}=\text { gdp }-0.25 \text { equip }-2.75 x / g d p-2.82 \text { rer }-0.70 h c \\
\mathrm{ecm}_{2(\mathrm{t}-1)}=\text { equip }-1.39 \mathrm{rd}\end{array}$} \\
\hline$\chi^{2}[20]=2$ & $.142[0.28$ & & & & & & & & & & \\
\hline
\end{tabular}

Table 6: Models Augmented with Infrastructures

\begin{tabular}{|c|c|c|c|c|c|c|c|c|c|c|c|}
\hline \multicolumn{12}{|c|}{ Productivity Model } \\
\hline & $\Delta \operatorname{prod}_{\mathrm{t}-1}$ & $\Delta$ equip $_{\mathrm{t}-1}$ & $\Delta \mathrm{rer}_{\mathrm{t}}$ & $\Delta$ rer $_{\mathrm{t}-1}$ & $\Delta \mathrm{rd}_{\mathrm{t}}$ & $\Delta \mathrm{rd}_{\mathrm{t}-1}$ & $\Delta \mathrm{x} / \mathrm{gdp}_{\mathrm{t}}$ & $\Delta \mathrm{x} / \mathrm{gdp}_{\mathrm{t}-1}$ & $\Delta$ rail $_{t-1}$ & $\begin{array}{c}\mathrm{ecm}_{1[\mathrm{t}-} \\
1)\end{array}$ & $\begin{array}{c}\mathrm{ecm}_{2[\mathrm{t}-} \\
1)\end{array}$ \\
\hline$\Delta \operatorname{prod}_{\mathrm{t}}$ & - & $\begin{array}{c}0.04 \\
{[3.50]}\end{array}$ & - & $\begin{array}{c}0.27 \\
{[6.00]}\end{array}$ & $\begin{array}{c}0.20 \\
{[9.36]}\end{array}$ & $\begin{array}{c}0.05 \\
{[3.23]}\end{array}$ & $\begin{array}{c}0.37 \\
{[4.76]}\end{array}$ & $\begin{array}{l}-0.75 \\
{[-6.30]}\end{array}$ & $\begin{array}{c}0.12 \\
{[5.16]}\end{array}$ & $\begin{array}{c}-1.73 \\
{[-8.79]}\end{array}$ & $\begin{array}{c}-\mathbf{- 0 . 0 8} \\
{[-3.39]}\end{array}$ \\
\hline$\Delta$ equip $_{\mathrm{t}}$ & $\begin{array}{c}-2.36 \\
{[-3.67]} \\
\end{array}$ & $\begin{array}{c}0.72 \\
{[5.56]}\end{array}$ & - & - & $\begin{array}{c}1.78 \\
{[8.68]}\end{array}$ & - & - & - & - & - & $\begin{array}{c}-1.13 \\
{[-4.77]}\end{array}$ \\
\hline \multicolumn{12}{|c|}{$\begin{array}{l}\mathrm{ecm}_{1(\mathrm{t}-1)}=\text { prod }-0.13 \text { equip }-5.94 x / \mathrm{gdp}-0.20 \mathrm{rail} \\
\mathrm{ecm}_{2(\mathrm{t}-1)}=\text { equip }-1.40 \mathrm{rd}\end{array}$} \\
\hline$\chi^{2}[16]=2$ & $049[0.0690$ & & & & & & & & & & \\
\hline
\end{tabular}




\begin{tabular}{|c|c|c|c|c|c|c|c|c|c|c|c|c|}
\hline \multicolumn{13}{|c|}{ Output Model } \\
\hline & $\Delta \mathrm{gdp}_{\mathrm{t}-1}$ & $\Delta$ equip $_{\mathrm{t}-1}$ & $\Delta \mathrm{rer}_{\mathrm{t}}$ & $\Delta \mathrm{rer}_{\mathrm{t}-1}$ & $\Delta \mathrm{rd}$ & $\Delta x / g d p$ & $\Delta \mathrm{x} / \mathrm{gdp}_{\mathrm{t}-1}$ & $\Delta$ rail $_{t-1}$ & $\Delta$ high & $\Delta \operatorname{high}_{\mathrm{t}-1}$ & $\mathrm{ecm}_{1(\mathrm{t}-1)}$ & $\mathrm{ecm}_{2(\mathrm{t}-1)}$ \\
\hline$\Delta \operatorname{gdp}_{\mathrm{t}}$ & - & $\begin{array}{c}0.04 \\
{[4.35]}\end{array}$ & - & - & $\begin{array}{c}0.21 \\
{[8.55]}\end{array}$ & - & $\begin{array}{c}-0.41 \\
{[-3.60]}\end{array}$ & 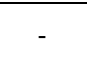 & & & $\begin{array}{c}\mathbf{- 3 . 7 0} \\
{[-7.72]}\end{array}$ & $\begin{array}{c}\mathbf{- 0 . 2 2} \\
{[-5.09]}\end{array}$ \\
\hline$\Delta$ equip $_{\mathrm{t}}$ & $\begin{array}{c}-2.37 \\
{[-4.33]}\end{array}$ & $\begin{array}{c}0.64 \\
{[6.69]}\end{array}$ & $\begin{array}{c}-1.35 \\
{[-3.47]}\end{array}$ & $\begin{array}{c}-1.37 \\
{[-3.44]}\end{array}$ & $\begin{array}{c}1.60 \\
{[8.23]}\end{array}$ & $\begin{array}{c}-1.46 \\
{[-1.90]}\end{array}$ & 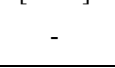 & $\begin{array}{c}-0.81 \\
{[-4.23]}\end{array}$ & & & - & $\begin{array}{c}-2.35 \\
{[-6.59]}\end{array}$ \\
\hline \multicolumn{13}{|c|}{$\begin{array}{l}e c m_{1(t-1)}=g d p-0.20 \text { equip }-3.98 x / g d p-1.04 \mathrm{rer}-0.45 \mathrm{rail} \\
e c m_{2(t-1)}=\text { equip }-1.40 \mathrm{rd} \\
\chi^{2}[18]=27.606[0.0683]\end{array}$} \\
\hline$\Delta \mathrm{gdp}_{\mathrm{t}}$ & $\begin{array}{c}-0.29 \\
{[-2.59]}\end{array}$ & $\begin{array}{c}0.04 \\
{[3.53]}\end{array}$ & $\begin{array}{c}-0.14 \\
{[-2.36]}\end{array}$ & - & $\begin{array}{c}0.23 \\
{[9.35]}\end{array}$ & $\begin{array}{c}0.56 \\
{[4.37]}\end{array}$ & $\begin{array}{c}-0.43 \\
{[-3.09]}\end{array}$ & & $\begin{array}{c}0.27 \\
{[6.04]}\end{array}$ & $\begin{array}{c}0.26 \\
{[5.00]}\end{array}$ & $\begin{array}{c}-2.25 \\
{[-7.97]}\end{array}$ & $\begin{array}{c}\mathbf{- 0 . 1 9} \\
{[-9.53]}\end{array}$ \\
\hline$\Delta$ equip $_{\mathrm{t}}$ & $\begin{array}{c}-1.76 \\
{[-2.76]}\end{array}$ & $\begin{array}{c}0.68 \\
{[5.93]}\end{array}$ & - & - & $\begin{array}{c}1.40 \\
{[7.12]}\end{array}$ & - & - & & - & - & - & $\begin{array}{c}-\mathbf{1 . 0 3} \\
{[-5.25]}\end{array}$ \\
\hline $\begin{array}{l}e c m_{1(t-1)} \\
e c m_{2(t-1)} \\
\chi^{2}[16]=2\end{array}$ & $\begin{array}{l}\text { dp }-0.18 \\
\text { quip }-0 \text {. } \\
32[0.08\end{array}$ & $\begin{array}{l}\text { quip }-4.99 \\
\text { ard }\end{array}$ & $p-0.8$ & & & & & & & & & \\
\hline
\end{tabular}

